\title{
TWO THEORETICAL APPROACHES TO HUMAN BEHAVIOR AND SOCIAL INSTITUTIONS
}

\author{
JAVIER ARANZADI DEL CERRO*
}

Resumen: Este artículo compara los modelos teóricos con los que se analiza la crisis económica que estamos sufriendo. Planteo la pobreza teórica ofrecida por el paradigma neoclásico dominante y defiendo la necesidad de nuevas aproximaciones teóricas que no estén obsesionadas por el método positivista. Mi argumento se basa en la obra de Ludwig von Mises quien fue considerado el economista que esgrimió los mejores argumentos tóricos en el debate sobre la imposibilidad de una cálculo económico eficiente en una económica de planificación central.

Aunque hoy en día se considera que la Escuela Austriaca está pasada de moda y falta de rigor científico, estoy de acuerdo con el difunto profesor Sumantra Ghoshal sobre la necesidad de abandonar los métodos encorsetados e intentar comprender los problemas económicos reales. Nuestra economía de mercado está sufriendo las consecuencias de lo que él describe como malas teorías que destruyen buenas prácticas empresariales.

Son estas las razones por las que pienso que el triunfo sobre el comunismo está en riego de convertirse en una victoria pírrica si perdemos nuestra comprensión de la economía de mercado y su estructura dinámica basadas en la empresarialidad y la empresa privada.

Palabras clave: Acción humana, Ludwig von Mises, Escuela de Chicago, empresarialidad, proceso de mercado, instituciones sociales.

Clasificación JEL: A10; B41; B53; D00.

Abstract: This paper deals with theoretical approaches to the real economic crisis we are suffering. I set out the poverty of the theoretical solutions offered by mainstream neoclassical economics and the necessity of a new theoretical approach, which is not obsessed by the positivist method. My argument is based on the work of Ludwig von Mises who was considered to give the best

* Associate Professor of Economics, Universidad Autónoma de Madrid. His last book is Liberalism against Liberalism, 2006, Routledge, London, javier.aranzadi@uam.es.

Procesos de Mercado: Revista Europea de Economía Política Vol. VIII, n.ํำ 1, Primavera 2011, pp. 13 a 50 
theoretical arguments in the debate on the impossibility of efficient economic calculation under centrally planned socialism.

Although nowadays the Austrian School is considered old-fashion and lacking in scientific rigour, I agree with the late Professor Sumantra Ghoshal that it is necessary to escape from strait-jacketed methods and try to understand real economics problems. Our market economy is suffering from what he described as the consequences of bad theories destroying good entrepreneurial practices.

For I do think that the triumph over communism is in danger of becoming a Pyrrhic victory if we lose our understanding of the market economy and its dynamic structure based on entrepreneurs and firms.

Key words: Human action, Ludwig von Mises, Chicago School, entrepreneurship, market process, social institutions.

JEL Classification: A10; B41; B53; D00.

\section{I \\ INTRODUCTION: ECONOMIC REALITY AND ECONOMIC THEORY}

Discussing market economics raises heated passions. People argue for or against it but they seldom clarify what they mean by it. They proclaim that it is the system that guarantees freedom, but will not the same thing happen to it as happened to Socialism, which claimed to be the defender of society, but which ended up by destroying it in the communist countries? Will not liberalism finally eliminate freedom, on the altar of economic efficiency?

These questions are important because now that communism has proved to be a failure, liberalism is being recommended as the only solution to economic and social problems. It is offered not as one of the solutions but as the only viable one. Its supporters recommend market liberalization and the elimination of trade barriers, while the scope of monetary calculation is being extended to phenomena which have never belonged to economics. Thus there are appearing the economics of law and the family, etc. People speak of «economic imperialism» that is invading the social sciences. 
But there is one fundamental question that must be explained. If it is acknowledged that it was Eugen Böhm-Bawerk, L. von Mises and F. Hayek, who offered the best arguments in favor of the market in the debate on economic calculation in a communist society; why then have their ideas been marginalized when it comes to offering a view of society? Why is pre-eminence given to neoclassical economics and their homo economicus? These questions were raised in the debate between S. Rosen (1997) and L. Yeager (1997). It is generally argued that the contributions of the Austrian School have been absorbed into the present liberal neoclassical paradigm Rosen (1997, p. 151). I consider this argument to be pretty questionable and the object of this article is to refute it. And the theoretical positions of the Austrian School and Chicago School do not converge as Yeager (1997, p. 164) says. The former is characterized by its construction of a theory of action, whose core is the creative capacity of people in their social and cultural environment. The latter reduce all human behavior to a mere optimization of functions with restrictions. And here arises the radical question in the present debate on the social sciences. Does the overcoming of socialism imply reducing man to the neoclassical homo economicus? And a last question: what is the result of applying the neoclassical model to resolving economic and social problems?

Before we address the core issue of our article, we must make two important remarks:

1) Articles on methodology are generally regarded as subsidiary, for the economist's task is considered to be to do economics. As Rosen rightly says:

Most of us prefer to assess serious attempts to do economics, rather than to spend time arguing over which methods should be used in those attempts. Instead of seeking a sure-fire method for ascertaining economic truth, which experience shows, is an impossible task, the more practical stance is to use whatever methods work best in practice. ${ }^{1}$

\footnotetext{
1 See Rosen (1997) p. 150.
} 
I do not wish to focus on Rosen's assertion of the theoretical impossibility of knowing the economic truth - a debate that would take us into the philosophy of science. On this point I would like to say just that, like Yeager (1997, p. 161), I advocate a realist scientific position. For the purposes of this article there is no need to enter into such philosophical complexities; what is needed, and here I agree with Rosen, is a theory that resolves people's real, practical problems. That is, the best economic theory is that which allows people to eat, have a house, job, car, etc. I do not deny the importance of a philosophical grounding for theory, but I tend to the Latin adage primum vivere, deinde philosophari. Now it was Mises who, from 1920, predicted the economic chaos brought about by a centralized economy. A real chaos which has condemned, and still condemns today in Cuba, North Korea, China, etc., millions of people to the most wretched economic situation. As Rosen acknowledges: «the collapse of central planning in the past decade has come as a surprise to most of us. Economists who early on questioned the reports of economic successes in socialist and communist economies were ignored, if not ridiculed, by many in the economics establishment. ${ }^{2}$

So from the realist and practical stance that I am taking here, the purpose of theory is to resolve people's real problems. This starting point as to the object of economic science leads to the following question: why is the importance of the Austrian School not recognized? Why does Rosen claim the following?

The paucity of quantitative empirical work in the Austrian tradition accounts for why so few Austrians are found in the professional economics community today. Their approach basically excludes most the things that most economists do. Austrians tend to disavow what they consider to be «routine» mathematical optimization problems that underlie much of empirical economics. ${ }^{3}$

Evidently the Austrian School is not judged from an objective and realistic stance. From the objective stance of the

2 Op. cit., p. 145.
3 Op. cit., p. 147. 
resolution and prediction of real economic problems, the works of Menger, Mises and Hayek are unassailable. So what criterion for comparison is used by most economists to judge the Austrian School? Simply the positivist neoclassical criterion that science is defined by quantitative method. That is, as Rosen says in the above paragraph, economics as a science is defined by the reduction of real problems to mathematical optimization problems. In other words, if you have no mathematical model, you are not an economist. As Yeager rightly says: He [Rosen] expects a more quantitative approach to remain dominant, thus already alluding to a market test and a notion than «dominant» means «better». ${ }^{4}$ The question arises of why the neoclassical model has this disregard of reality Bauer (1987). A pertinent charge is leveled against the neoclassical model of trivializing real economic problems to the point of reducing them to the maximization of an objective function with restrictions. As Yeager says: «economics turns into applied mathematics or engineering». ${ }^{5} \mathrm{~A}$ supposed scientificity is sought by copying the method of physics Miroswki (1989). S. Ghoshal (2005) acknowledges and demonstrates the consequences of applying the neoclassical model to resolving real business problems. The article's title could not be more telling: «Bad management theories are destroying good management practices». Ghoshal says:

Rejecting what we saw as the «romanticism» of analyzing corporate behaviors in terms of the choices, actions, and achievements of individuals..., we have adopted the «scientific» approach of trying to discover patterns and laws, and have replaced all notions of human intentionality with a firm belief in causal determinism for explaining all aspects of corporate performance. In effect, we have professed that business is reducible to a kind of physics in which even if individual managers do play a role, it can safely taken as determined by the economic, social, and psychological laws that inevitably shape peoples' actions. ${ }^{6}$

\footnotetext{
4 Yeager (1997) p. 156.

5 Op.cit. p. 158.

${ }^{6}$ Ghoshal (2005) p. 77.
} 
The idea of explaining economic reality with a mechanical model is a consequence of the neoclassical model's internal logic. Rosen recognizes the surprise of the great majority of economists at the actual failure of socialism. But he does not recognize that this failure is the logical consequence of the neoclassical model's hypotheses. In other words, for the neoclassical model, socialism is a theoretical possibility just as feasible as the market economy. Rosen says:

"after all, the "central planning problem" is equivalent to a market solution, given the specification of technology and tastes. If the conditions of the welfare theorem hold, the answer can be applied directly to the data without studying individual maximizing decision at all». ${ }^{7}$

Here is the key to the neoclassical model's theoretical failure. That model's hypotheses and methods are not suited to explaining human action. The use of the maximizing behavior hypothesis, expressed in homo economicus, allows the theoretical solution of a centralized economy. And, moreover, the use of such hypotheses does not allow the behavior of flesh and blood entrepreneurs to be explained. Rosen says: «entrepreneurs are not to be found in neoclassical economics». ${ }^{8}$ In other words, the neoclassical model cannot explain the real problems of a socialist economy in theoretical terms, and moreover, according to that model, socialism should work, and it is unable to explain why a real market economy based in firms works.

We could say with Ghoshal: (1) the neoclassical model is a bad theory that cannot explain a bad practice (socialism), and (2) it is a bad theory that has disastrous consequences when applied to resolving real business problems. As Ghoshal rightly says:

Combine agency theory with transactions costs economics, add in standard versions of game theory and negotiation analysis, and the picture of the manager that emerges is one that is now very familiar in practice: the ruthlessly hard-driving, strictly top-down, command-and-control focused, shareholder-value-

\footnotetext{
7 Rosen (1997) p. 144.

8 Op. cit., p. 148.
} 
obsessed, win-at-any-cost business leaders of which Scout Paper's «Chainsaw» Al Dunlap and Tyco's Dennis Kozlowski are only the most extreme examples. This what Isaiah Berlin implied when he wrote about absurdities in theory leading to dehumanization of practice. ${ }^{9}$

2) There is another issue to resolve, closely related to the above point. Here it is worth recalling this article's initial question: why is the neoclassical model regarded as the model to be used, i.e. the dominant scientific paradigm, while other theories are systematically ignored? In analyzing the current situation Ghoshal asks the same question:

What is most curious is that despite the lack of both face validity and empirical support, agency theory continues to dominate academic research on corporate governance... Why do we not fundamentally rethink the corporate governance issue? The honest answer is because such a perspective cannot be elegantly modeled - the maths does not exist. Such a theory would not readily yield sharp, testable propositions, nor would provide simple, reductionist prescriptions. ${ }^{10}$

The answer offered to this critique is perfectly formulated by Rosen: "What is the fact that neoclassical economics has scored higher than Austrian economics on the evolutionary / survival test telling us?»11 This is the famous «market test» of ideas. A clearly neoclassical criterion. As Yeager (1997) rightly says, it is pretty questionable to regard the academic world as a competitive market. Its only application would be a monopoly led by the neoclassical model and the neoclassical School. Yeager says: «He [Rosen] evidently holds it against the Austrians that they not pass his market test in the intellectual atmosphere created by members of his own camp, an atmosphere pervaded by narrow yet tacit methodological preaching». ${ }^{12}$ This point is not strictly theoretical but it

\footnotetext{
9 Ghoshal (2005) p. 85.

10 Op. cit., p. 81.

11 Rosen (1997) p. 151

12 Yeager (1997) p. 159.
} 
illustrates the current situation. Rosen's viewpoint is generally accepted. And the critiques set out in this article and expressed by Ghoshal and Yeager are simply ignored. Why? This is easy to explain, but very hard to remedy. The explanations given by Ghoshal and Yeager seem correct to me, though I would like highlight one aspect. In practical terms, what is at stake in economics is the neoclassical school's monopoly over the management of global economic affairs.

As Keynes correctly pointed out: «the ideas of economists and political philosophers, both when they are right and when they are wrong, are more powerful than is commonly understood... Indeed the world is run by little else». ${ }^{13}$ I quite understand the neoclassical stance, its stalwart defense of its model, its methodology and its power of action through political activity. Evidently from the stance advocated here the methodology is different and so the aspiration to conduct active economic policy based on a scientist interpretation or a fine tuning engineering solution of social problems disappears. Our aim as economists must be the resolution of real problems, without imposing any method a priori. The current crisis, with its constant corporate and financial scandals, is having a very dangerous effect. It is calling into question the role of the market economy and the importance of the firm as a social institution. As Ghoshal says: «Of far greater concern is the general delegitimimation of companies as institutions and of management as a profession». ${ }^{14}$ Is it not more important to resolve the current crisis than to spend our time resolving academically prestigious mathematical problems? As H. Simon points out and Ghoshal echoes: «nothing is more fundamental in setting our research agenda and informing our research methods than our view of the nature of human beings whose behaviors we are studying... It makes a difference to research, but it also makes a difference for the proper design of.... institutions». ${ }^{15}$

\footnotetext{
${ }^{13}$ Keynes (1953) p. 306.

14 Ghoshal (2005) p. 76.

15 Simon (1985) p. 292.
} 


\section{II}

\section{THE SCOPE OF ECONOMICS ${ }^{16}$}

There exists a general idea as to what phenomena is the proper object of economic science. Many people agree that the aim of this branch of knowledge is to investigate market phenomena, that is, to enquire into the nature of the types of exchange that exist between the various goods and services. The difficulties of economic analysis do not come from any uncertainty over precisely what the object of the study is. The problems arise when we try to explain what constitutes the economic behavior, which causes these market phenomena. While on the other hand, the explanation of economic behavior allows us to delimit the area in which the economic phenomena originate.

Although it is true that economics began with the study of market phenomena, it was however necessary to go beyond the sphere of the market itself and of the mercantile transactions in order to explain these phenomena. The marginal revolution supposed a generalization of the field of economics as a result of an enlargement of the anthropological basis, which supports the explanation of economic behavior. The most important and radical advance has been to confirm that all economic behavior is based on the same elements that conform any action. The explanation that we give of economic behavior will allow us to include within the scope of economics many types of behavior that are not market exchanges, since when we talk about economic behavior we are dealing with concepts of preference, valuation, choice, ends and means. These are all concepts that are present in the explanation of any human behavior. This coincidence, that seems to be obvious and is often overlooked, determines the scope and potency of economic science, depending on the response that is given to the following three questions:

- Question 1: If in order to explain the phenomena of the market, it is necessary to go beyond the market transactions, what is

\footnotetext{
16 What follows is an abridged version of Aranzadi (2006).
} 
the scope of Economics? Does Economics include mercantile and non-mercantile transactions?

- Question 2: If, as we have said, the basic elements of economic behavior are to be found in every action, is it permissible to ask ourselves, what is the difference between market phenomena and non-mercantile phenomena?

- Question 3: And very closely linked to the second question, we can pose the following question; can all human behavior be reduced to market transactions?

In this article we are going to analyze the work of two authors, Ludwig von Mises and Gary Becker because, from their different schools, they give consistent answers to these three questions. Unlike the approach of Rosen, who regards the Austrian model as a macroeconomic theory, ${ }^{17}$ the work of Mises will allow us to present the Austrian microeconomic theory that explains individual behavior (Praxeology), which is the basis for explaining social interrelations. As Yeager says: «Austrians are concerned with the big picture, with how a whole economic system functions, and with alternative sets of institutions. This is what Rosen presumably means by curiously labeling Austrian economics a "macro" rather than "micro" theory». ${ }^{18}$ The methodological individualism propounded by Mises is based on: (1) the explanation of individual action. (2) Action in the social framework: social interrelations.

Gary Becker, the winner of the Nobel Prize for Economics, offers another theoretical proposition. In the book written in his maturity, The Economic Approach to Human Behavior Becker (1976) he establishes the assumptions which define economic behavior. In his own words, «the combined assumptions of maximizing behavior, market equilibrium, and stable preferences, used relentlessly and unflinchingly, form the heart of economic approach». ${ }^{19}$ These three assumptions, which define economic behavior, are enough to reduce all human behavior to economic behavior. There are no doubts as to the object that Becker is proposing: «I do not want to

\footnotetext{
17 Rosen (1997) p. 140.

18 Yeager (1997) p. 154.

19 Becker (1976) p. 5.
} 
soften the impact of what I am saying in the interest of increasing its acceptability in the short run. I am saying that the economic approach provides a valuable unified framework for understanding all human behavior. ${ }^{20}$ Becker contributes a specific determinant of economic behavior, called homo economicus, which allows him to respond affirmatively to the third question, about it being possible to reduce all human behavior to homo economicus.

Both Mises and Becker consider that the scope of Economics includes the whole of human behavior, although the characteristics of economic behavior, which support this statement, are totally different in the two authors. We must distinguish two subjects, in their work, which are very closely related to the three questions presented under the previous heading: (1) the justification of the end pursued together with the enlargement of the scope of Economics. (2) The theory provided for such an end that is the characterization of economic behavior. The theoretical doctrine, which each author offers, determines a different method of economic analysis. In this section, we shall see how Mises and Becker respond to the first question, and then in the next section, we shall analyze their theoretical responses to the two remaining questions.

Mises and Becker's motive for enlarging the scope of Economics is their dissatisfaction with the current theories. Mises (1981) deals with the criticism of the principle of economic rationality of the classical school of economics because it does not take into account those motives that cannot be expressed in money terms. Mises argues that economic theory has become an objective science by enlarging the subjective base of economic behavior. The characteristic that defines economic behavior is the unchangeable reality of having to make choices between scarce means and alternative ends. Therefore, for Mises the scope of Economics includes every action where the human agent chooses between different alternatives in order to change his current situation. Mises establishes the fact that the end pursued does not characterize the economic principle or the means that are used. ${ }^{21}$ The essence

20 Op. cit., p. 14.

21 Mises (1996). 
of economic behavior is the unchangeable choice between different alternatives created in the action. He rejects the following lines of research:

(1) It is a vain effort, if we start from the study of market phenomena, and if we try to delimit its scope by appealing to the motives, which impel men to act, or to the nature of the objectives, which the action may pursue in each case. In Mises' words: "the classification of actions according to their various motives may be momentous for psychology and may provide a yardstick for a moral evaluation; for economics it is inconsequential».22

(2) Another line of research that is destined to fail is that of limiting the field of economics to those human actions, whose objective is to provide people with tangible, material goods from the external world. Mises argues:

The advice of a doctor, the instruction of a teacher, the recital of an artist, and other personal services are no less an object of economic studies than the architect's plans for the construction of a building, the scientist's formula for the production of a chemical compound, and the author's contribution to the publishing of a book..$^{23}$

These two lines of research do not allow us a better understanding of market phenomena because the essence of economic behavior is neither the nature of the end pursued, nor the nature of the means used. The economist's only responsibility is to confirm the existence of a dissatisfaction, which motivates the person to act, and that the agent perceives or realizes that certain goods, be they material or immaterial, may serve him as a means.

These considerations that Mises makes about the theoretical paths that must be abandoned are also present in the work of Becker: (1) Economic access to reality, according to Becker,

22 Op. cit., p. 233

23 Op. cit., p. 233. 
normally finishes when it bumps up against tastes. So, «in the traditional vision, an explanation of economic phenomena reaches its limit when it meets the difference in people's tastes». ${ }^{24}$ In face of this traditional vision, Becker offers an alternative vision, in which, «The economist continues the search for differences in prices or income, in order to explain any difference or change in behavior».$^{25}$ The essence of economic behavior is not based on the motives or tastes, which define the end that is pursued. (2) Neither is economics restricted to the study of material goods. The economic means may be both material and immaterial. The following paragraph by Becker is quite explanatory:

The definition of economics in terms of material goods is the narrowest and the least satisfactory. It does not describe adequately either the market sector or what economists «do». The production of tangible goods now provides less than half of the market employment in the United States, and the intangible outputs of the service sector are now larger in value than the outputs of the goods sector. Moreover, economists are as successful in understanding the production and demand for retail trade, films or education as they are for autos or meat. ${ }^{26}$

For both authors economic behavior is based neither on the ends nor on the means. The definition of economics in terms of scarce means and alternative ends presents the following problem, which has so accurately been posed by Becker:

This definition of economics is so broad, that it is often a source of embarrassment rather that a source of pride to many economists, and usually, it is immediately qualified to exclude the greater part of non-market behavior. [This definition] simply defines the scope, none tell us one iota about what the «economic» approach is. ${ }^{27}$

\footnotetext{
24 Stigler and Becker (1977) p. 76.

25 Op. cit., p. 76.

26 Becker (1976) p. 4.

27 Op. cit., p. 4.
} 
We must ask ourselves, where must we look for the essence of economic behavior? The nature of the economic problem cannot be resolved by studying the ends and means that are used in the market. The area, in which actions are produced, based on the scarcity of means and the need to make choices, exceeds the area of market phenomena. Both Mises and Becker are fully aware that in all human behavior there is a choice between different courses of action. In other words, every choice supposes a benefit and implies a cost, Therefore, the scope of Economics includes for both authors many more phenomena than those of the market. Becker has pointed out different phenomena, which are not market phenomena but in which a choice is produced:

Scarcity and choice characterize all the resources allocated by the political process (including which industries to tax, how fast to increase the money supply, and whether to go to war); by the family (including decisions about a marriage mate, family size, the frequency of church attendance, and the allocation of time between sleeping and waking hours); by scientists (including decisions about the allocating their thinking time, and mental energy to different research problems) and so on, in endless variety. ${ }^{28}$

It is clear that question (1): enlarging the scope of Economics poses the second and third questions asked at the beginning of this paper. It is necessary to determine exactly what is understood by economic behavior because the two problems, already mentioned, are presented here.

III

TWO ECONOMIC APPROACHES TO HUMAN BEHAVIOR

Bearing in mind that both authors are attempting to study every aspect of human behavior, the problem that we face is not a

\footnotetext{
28 Op. cit., p. 4.
} 
simple choice between two technical models. We are not dealing with a choice based on the inclinations of the researcher. Our critical analysis and therefore our choice must be based on seeking the most suitable and appropriate model for the study of human behavior.

The comparison of the Praxeology of Mises and the homo economicus of Becker makes it clear that they are not two alternative models, but perfectly valid models. In other words, the characterization of economic behavior made by Becker implies such severe restrictions, that the theoretical validity of its application is restricted to phenomena that are limited and of little analytical importance. This does not mean to say that the neoclassical model is totally unimportant. As I. Kirzner recognizes, phenomena of practical importance, such as the effects of price controls, and minimum wage laws can be explained with simple neo-classical models. ${ }^{29}$

However, the characterization of homo economicus cannot include any characteristic that defines the man of flesh and blood: his historicity, his project, and his futurity. In short, the person's own dynamic is excluded from homo economicus for these characteristics are displayed in all human behavior. And if we take into account that a market phenomenon is the result of human action, then it is not necessary to go beyond the sphere of the market to demonstrate the radical insufficiency of neoclassical proposals. It is important therefore to emphasize that it is incorrect to consider Praxeology as a valid model to explain non-monetizable phenomena and at the same time to use the neoclassical model to explain market phenomena.

In our argument it is necessary to distinguish two elements.

\section{Theoretical differences}

The theoretical doctrines of each author are exposed in Table 1 below. ${ }^{30}$

\footnotetext{
${ }^{29}$ Kirzner (1997) p. 62

30 See Huerta de Soto (1998).
} 
TABLE 1

THEORETICAL DIFFERENCES

\begin{tabular}{|c|c|c|}
\hline Point of comparison & $\begin{array}{c}\text { Ludwig von MISES } \\
\text { Austrian School }\end{array}$ & $\begin{array}{c}\text { G. BECKER } \\
\text { Neoclassical School }\end{array}$ \\
\hline $\begin{array}{l}\text { 1. Concept of the economic } \\
\text { point of view: } \\
\text { Protagonist of the social } \\
\text { process. }\end{array}$ & $\begin{array}{l}\text { Theory of human action } \\
\text { understood as a dynamic } \\
\text { process: Praxeology: The } \\
\text { real man. }\end{array}$ & $\begin{array}{l}\text { Decision theory based } \\
\text { on maximization with } \\
\text { restrictions: Homo } \\
\text { economicus } 1^{\text {st }} \text { hypothesis: } \\
\text { Maximizing behavior. }\end{array}$ \\
\hline $\begin{array}{l}\text { 2. Definition of the } \\
\text { means-end relation. }\end{array}$ & $\begin{array}{l}\text { Discovery of means and } \\
\text { creation of possibilities. }\end{array}$ & $\begin{array}{l}\text { The means and ends are } \\
\text { «given». }\end{array}$ \\
\hline $\begin{array}{l}\text { 3. Dynamism of the key } \\
\text { concept. }\end{array}$ & $\begin{array}{l}\text { The person constructs his } \\
\text { structure of means and } \\
\text { ends in the exercise of } \\
\text { entrepreneurship; it is a } \\
\text { dynamic structure. }\end{array}$ & $\begin{array}{l}\text { Static and temporal } \\
\text { analysis of choice when } \\
\text { facing given alternatives. }\end{array}$ \\
\hline 4. Concept of competition. & $\begin{array}{l}\text { Dynamic process of } \\
\text { discovery }\end{array}$ & $\begin{array}{l}2^{\text {nd }} \text { Hypothesis: model of } \\
\text { market equilibrium. }\end{array}$ \\
\hline 5. The project. & $\begin{array}{l}\text { The end is projected going } \\
\text { beyond the statistically } \\
\text { given: the future is } \\
\text { something to be done. }\end{array}$ & $\begin{array}{l}3^{\text {rd }} \text { hypothesis: stability of } \\
\text { preferences over time. The } \\
\text { future is a repetition of } \\
\text { the past. }\end{array}$ \\
\hline $\begin{array}{l}\text { 6. Division between areas } \\
\text { of study. }\end{array}$ & $\begin{array}{l}\text { Essential difference } \\
\text { between: } \\
\text { a) non-monetizable social } \\
\text { interrelations. } \\
\text { b) Monetizable market } \\
\text { exchanges }\end{array}$ & $\begin{array}{l}\text { There is no difference } \\
\text { between areas. Every } \\
\text { decision is quantifiable by } \\
\text { means of market prices or } \\
\text { shadow prices. }\end{array}$ \\
\hline 7. Concept of society. & $\begin{array}{l}\text { Tendency to the } \\
\text { coordination of social } \\
\text { interrelations. }\end{array}$ & $\begin{array}{l}\text { The social framework is } \\
\text { exogenous to the model. } \\
\text { In the extended utility } \\
\text { function there appears } \\
\text { social capital, which } \\
\text { includes the social } \\
\text { elements. }\end{array}$ \\
\hline 8. Concept of culture. & $\begin{array}{l}\text { Cultural transmission of } \\
\text { the possibilities of action. }\end{array}$ & $\begin{array}{l}\text { The cultural framework is } \\
\text { exogenous to the model. } \\
\text { In the extended utility } \\
\text { function, there appears } \\
\text { the social capital, which } \\
\text { includes the cultural } \\
\text { elements. }\end{array}$ \\
\hline 9. Structure of the model. & $\begin{array}{l}\text { Praxeological categories, } \\
\text { universal and necessary. } \\
\text { Dynamic structure of the } \\
\text { action. }\end{array}$ & $\begin{array}{l}\text { The three hypotheses } \\
\text { determine, as a condition } \\
\text { of equilibrium, the } \\
\text { equality of marginal } \\
\text { utilities weighted by prices. }\end{array}$ \\
\hline
\end{tabular}


1) Concept of the economic point of view:

Protagonist of the social process

The extreme divergence presented by the two works from the beginning strikes us forcefully. From the very first moment they build their theoretical bases in such a way that no convergence is possible. Mises moves within the broader field. He starts from human action, understood as the process of change from unsatisfactory situations to other more satisfactory ones: this is the axiom of action.

If, following Becker, there is no need to study man: that is, the subjective aspect of the action. It is enough for us to define a series of coherent hypotheses, which define a being called homo economicus who must be the agent of the changes in the model. In fact, this economic agent is not active; he is not a person of flesh and blood. To move within the study of the person as he really is, it is necessary to follow the Misesian Praxeology and focus on man and investigate the origin of the changes. Using Praxeology and starting from the Mises' work, Kirzner has established the lines along which to develop the key concept of entrepreneurship. This function is not the exclusive patrimony of any group, but is exercised by everyone who acts. More than objective information, entrepreneurship is the subjective capacity of managing objective information. With this scheme, Misesian Praxeology is directed towards the person, to the study of the subjective aspect of the action.

Becker reduces economic behavior to operating with elements that homo economicus can manage. His principal hypothesis and the basis of his work are to assume maximizing behavior. It is clear that this behavior does not have the minimum connotation of the inherent creativity of the human being. This homo economicus maximizes when faced with the alternatives that are offered to him and which are determined by the decision that is being studied. In other words, homo economicus is a mere passive optant. 
2) Definition of the means-end relation

The proper object of economic science, the means-end relation is treated totally differently by the two authors. For the Austrian School the means-end relation is dynamic. Each person in the exercise of entrepreneurship discovers means and ends and creates possibilities of action. He discovers new possibilities of action in the physical-chemical properties of the things. Things may be there as resources, but until someone discovers a possibility of action in them, they cannot be considered as a means. To advance in the understanding of each individual action, it is necessary to investigate the motives of the subject of the action. The person, the subject of the action, is made the object of praxeological study. Obviously we are not discussing given means and ends. In Praxeology, not only the ends but also the means are only comprehensible in relation to the person. For his part, Becker attempts to make the means-end relation, «objective», so that he can work with the «data». He begins the process of separating this relation from its framework of reference: human action.

\section{3) Dynamism of the key concept}

Entrepreneurship cannot be reduced to a factor of production or to objective knowledge. Its exercise becomes real in the structuring of the means and the ends in projects. But it is fundamentally important to make it clear that the creative capacity of the person is dynamic. Entrepreneurship is not dynamic because it is developed in time, but because it goes beyond what is immediately given. This dynamism which entrepreneurship develops is the transformation of the action. Mises defined entrepreneurship as follows:

Economics, in speaking of entrepreneurs, has in view not men, but a definite function. This function is not the particular feature of a special group or class of men; it is inherent in every action and burdens every actor. In embodying this function in an 
imaginary figure, we resort to a methodological makeshift. The term entrepreneur as used by catallactic theory means: acting man exclusively seen from the aspect of the uncertainty inherent in every action. In using this term one must never forget that every action is embedded in the flux of time and therefore involves a speculation. The capitalists, the landowners, and the laborers are by necessity speculators. So is the consumer in providing for anticipated future needs. There's many a slip «twixt cup and lip». ${ }^{31}$

This is the basic concept to understand, that the end is an imagined reality and that the means must be constituted. The explanation of economic phenomenon exceeds and encompasses the assignable aspects that it contains. Praxeology emphasizes the process, not the isolated acts which shape the action as a process. Therefore, if we pay attention to the dynamic structure, the key element that enables us to understand the assignable acts is the inherent dynamism of the process.

The economic behavior explained by Becker can only be static; it is about isolated acts, which taken out of their framework of reference are presented as isolated decisions. Dynamism is not possible in this model. Everything is reduced to a static and atemporal analysis, which is incapable of integrating the dynamism of the person. In reality, Becker's definition of economic behavior leaves out the essence of Economics: the man of action. As Rosen recognizes:

Entrepreneurs are not to be found in neoclassical economics. The term does not appear in the indexes of the main graduate texts on economic theory, nor is the concept mentioned in any context or under a different name. The fact is that there is no role for entrepreneurs when economic conditions are "given», when the list of goods to be traded is cut and dried, when consumers and producers are clearly identified, and when resource availabilities are known. ${ }^{32}$

31 Mises (1996) p. 252.

32 Rosen (1997) p. 149. 


\section{4) Concept of competition}

In Praxeology, competition is a dynamic process of discovery. That is the discovery of the means and ends in the whole scope of application of entrepreneurship, which in other words, is the social world. This process of competition has no negative connotations because the social interrelations and the market exchanges tend to coordinate the expectations, provided that the person complies with the moral norms. Using the expression used in game theory, we can say that the interrelations and the market exchanges are positive sum. The expansion of the possibilities of action, of disposing of greater means is the consequence of the fact that competition is a positive sum game. Becker introduces his second hypothesis of market equilibrium. Once he totally eliminates the dynamism from his scheme, Becker works with systems of simultaneous equations that represent atemporally all the elements that enter the means-end relation.

Therefore, the neoclassical model does not move in a dynamic process. He moves in isolated points of decisions that are already known. His approach to behavior can be reduced strictly to an explanation of known decisions. Rosen says on this point: «neoclassical dynamism is basically represented as a moving equilibrium process rather than as an Austrian-style perpetually disturbed disequilibrium». ${ }^{33}$ As Kirzner states in this respect: "he is going to identify (the real problem) with the movement of one known equilibrium position to another, with the "innovations" and with the dynamic changes but not with the dynamics of the same process». ${ }^{34}$

So, I can conclude that neoclassical concept of competition is «static» whereas the Austrian concept is «dynamic». But these two approaches mean a very different concept of the firm. For the neoclassical model its existence is something quiet problematic. When Coase ([1937] 1988) asked, why firms come to existence? Williamson gives us this astonishing answer: «the firm is the organizing form of last resort to be employed when all else

\footnotetext{
33 Op. cit., p. 159.

34 Kirzner (1973) p. 27.
} 
fails». ${ }^{35} \mathrm{H}$. Simon raises the problem for the neoclassical model: «The description of the parties who participate in these transactions is minimal. However as soon as firms are elaborated to become more than simple nodes in a network of transactions, to be producers, difficult and important questions arise for the theory». ${ }^{36}$ So, much of our modern world's business is carried in an economics of organizations, in which could be a more realistic assumption saying «markets as beginning where organizations fail». ${ }^{37}$

Even more as Ghoshal, Bartlett and Moran (1999) say: «corporations, not abstract economic forces or governments, create and distribute most of an economy's wealth, innovate, trade and raise living standards». 38 These two different concepts of the firm give two different concept of competition «static» or «dynamic». Moran \& Ghoshal say on this point:

At the heart of these different perspectives on the role of the firm lies ... a different view about the concept of efficiency itself. In much conventional economics, efficiency is a static concept, as is appropriate in acontextual, equilibrium analysis. However, in a more contextual and dynamic view, the notion of efficiency is much more problematic. ${ }^{39}$

And these different approaches of efficiency have, as consequence, a very different vision on the economic process. From a «static» point of view the resources are "given» so in any economy interchange what one person wins is the other person's lose. As Ghoshal, Bartlett and Moran say: "Static efficiency is about exploiting available economic options as efficiently as possible... In this zero-sum world, profits must indeed come at the expense of the broader society». ${ }^{40}$

\footnotetext{
35 Williamson (1991) p. 279.

36 Simon (1991) p. 25.

37 Rumelt, Schendel, \& Teece (1991) p. 19.

38 Ghoshal, Bartlett and Moran (1999) p. 9.

39 Moran \& Ghoshal (1999) p. 407.

${ }^{40}$ Ghoshal, Bartlett and Moran (1999) p. 12.
} 


\section{5) The project}

The historicity of the person has two aspects: the temporal flow and the project. From the inevitable flow of time, the person imagines more desirable situations and tries to make them possible. This attempt to organize the means to try to attain the desired end is the activity of pure entrepreneurship. Therefore, a project is the creative integration of the means to attain the end. In other words, human reality is fluid because it is historical and it is projective because it is open to the future. ${ }^{41}$ As Yeager points out: "[Austrians] emphasize the openness of the future and scope for novelty». ${ }^{42}$ This projection into the future is formed in the synoptic structure of the project, consisting of the mental representation that the person forms of the different stages leading to the end.

Becker's position on this point is new with respect to other authors. Aware of the problem that time poses for generalizing the neoclassical model for all human behavior, he introduces the hypothesis of the stability of preferences over time of the extended utility function. This hypothesis is simply the logical consequence of the two previous one. If we consider that the future is a repetition of the past, this third hypothesis postulates that the choices that homo economicus would like to make in the future, if he knew what would happen in the meantime, are exactly the same choices that he would then really make. This hypothesis constitutes what he defines as the anticipatory behavior of the person.

\section{6) Division between areas of study}

We can answer now questions 2 and 3 presented at the beginning of this article. The work of Mises offers clear answers to the second and third questions. The question 2 is answered by saying

\footnotetext{
${ }^{41}$ Obviously, in every project, there exists the difficulty of the management of the productive factors. These technical difficulties, in spite of being fundamental, are outside the scope of our study. If we focus on the dynamism of pure entrepreneurship, these technical difficulties are faced, because previously a possible future gain is perceived.

42 Yeager (1997) p. 156.
} 
that Economics is converted into a general theory of action in such a way that the principle of economic behavior is converted into a principle of action. This conversion allows him to distinguish within the general theory of action between economic actions and non-economic actions, the former being understood as constituted by market phenomena and the latter as being constituted by social interactions. If we use Mises' terminology, the first actions are called catalactic actions or market actions and the second actions are called praxeological or social interactions. The response to question 3 is negative. It is impossible to reduce all human behavior to economic behavior, if we understand economic behavior, as what can be expressed in monetary terms. As Mises enjoyed mentioning, Praxeology or general theory of action includes catalactics or the theory of the market.

FIGURE 1

FIELDS WITHIN HUMAN ACTION

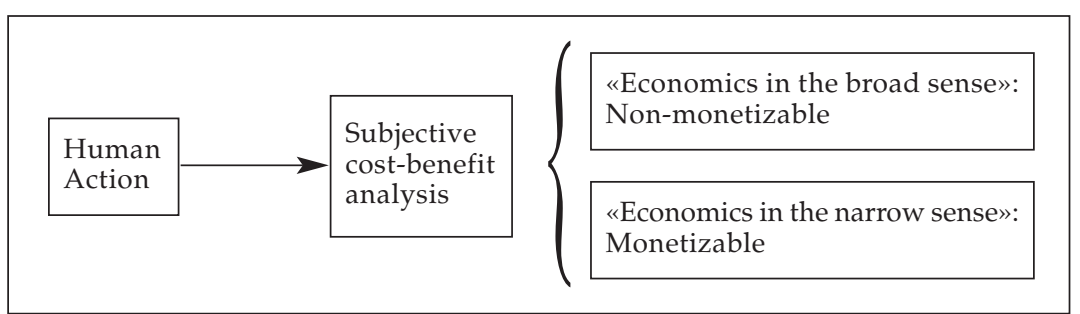

The interdisciplinary vocation is patent in the Misian division of «Economics in the broad sense» and «Economics in the narrow sense». To answer question 1, Mises has to recognize that the fundamental categories necessaries to explain price formation are the requisites of every human action. As Mises says: «The special characteristic of economic calculation is that the sphere of its use seems to be a special province within the broadest dominion of every action». ${ }^{43}$ Within the common theoretical base there exists a clear difference between the non-monetizable social

${ }^{43}$ Mises (1981) p. 157. 
interrelations and the monetizable market exchanges. In the first of these, we can cite the family, law, social institutions, ethics, etc. Everything that is essentially human is included. Therefore, Praxeology has never proposed the monetization of all human action, as Becker does with the generalization of homo economicus. As Mises clearly says:

It is absurd to want to apply the elements of this calculation (cost-benefit) to different problems, other than those confronting the individual person. One may not extend them to res extra commercium. One may not attempt by means of them to include more than the sphere of the economic in its narrower sense. However, this is precisely what is attempted by those who undertake to ascertain the monetary value of human life, social institutions, national wealth, cultural ideals, or the like, or who enter upon highly sophisticated investigations to determine how exchange ratios of the relatively recent, not to mention the remote, past could be expressed in terms of our money. ${ }^{4}$

\section{7) Concept of society}

Every action, whether it is social interaction, or a market exchange, is carried out within some social institutions. Every action is developed in an institutional framework. The institutions make it possible for the expectations of the persons to concur and that the mutual benefit of the relations is guaranteed. That is to say, the process of social institutionalization guarantees the coordinating tendency of the expectations. I can define the institutions as the regular forms of life in common of individuals. So any institution realizes three functions: (1) Satisfy needs. (2) Coordinate the behavior of individuals. (2) Provide norms of conduct and values shared by individuals. As D. North (1991) says: «Institutions are the humanly devised constraints that structure political, economic and social interaction. They consist of both informal constraints

\footnotetext{
${ }^{44}$ Op. cit., p. 159.
} 
(sanctions, taboos, customs, traditions, and codes of conduct) and formal rules (constitutions, laws, property rights)». ${ }^{45}$

In this model, institutions constitute an integrated system where the expectations of the roles are rule-governed. This rule must be interpreted as a reciprocal stabilization of conduct. With this conception of expectations, one can explain the origin of the division of labor, which is the basis of economic progress. The division of labor is an expectation of the role. It is a particular case of great importance in the process of institutionalization. The division of labor is a role insofar as it enables people to specialize in a task, and to expect the exchange of the goods produced by each person. This possibility of exchange is what the market economy is based on; this typification of the expectation in the exchange is based on the fact that the division of labor has become rule-governed, it has become institutionalized. In this view I can understand perfectly what Moran \& Ghoshal say about firms: «Each firm creates a unique subsidiary context, consisting of its own unique mix of incentives that encourages the assimilation, sharing, and combination of resources». ${ }^{46}$ (1999: 407).

In Becker's work, all reference to the social institutions and to the social interrelations is reduced to arguments that appear in the variable social capital of the extended utility function. All their complexities are reduced to mere external data.

\section{8) Concept of culture}

The social institutions constitute the framework that sustains the social «edifice». But the possibilities of action are transmitted in society through culture. Tradition is the treasure that is transmitted from generation to generation; it is the set of possibilities of action that are handed down to future generations. As Mises says:

[The fundamental thing about culture] is the assimilation of ideas that roused mankind from the inert routine of a merely

45 D. North (1991) p. 97.

46 Moran \& Ghoshal (1999) p. 407. 
animal existence to a life of reasoning and speculating. It is the individual's effort to humanize himself by partaking in the tradition of all the best things that earlier generations have bequeathed. ${ }^{47}$

But these possibilities, that are transmitted, have to be accepted by the recipients. These received possibilities must guarantee, to the present generation, the development of their creative capacity. The social institutions have their own dynamism, which depends on the opportunities that enable their members to exercise their entrepreneurship. Every social institution has to guarantee the persons' development of entrepreneurship. In the case of work, for example, the decision to specialize is based on the fact that the division of labor is the behavioral norm. With these remarks we can conclude that we need the culture and society to understand the importance of pure entrepreneurship, since man discovers the means of action in society through culture.

With the praxeological categories social evolution is explained as the cultural transmission of the possibilities of action. Through individual actions, the elements that are received are culturally altered, thus expanding the field of social interactions and market exchanges. So we can explain why the medieval world had fewer possibilities of action than our own. This cultural dimension of social institutions is of maximum importance. The unity of meaning of the institutions enables them to be dynamic. The institution has not only made it possible to achieve the ends desired in the past, but it has to make it possible, in each present action, to achieve the ends that each person determines. As North points out:

They [institutions] evolve incrementally, connecting the past with the present and the future; history in consequence is largely a story of institutional evolution in which the historical performance of economics can only be understood as a part of a sequential story. ${ }^{48}$

Schumpeter (1947), the Austrian economist, spoke of creative destruction, implying with this concept that every economic

47 Mises (1966) p. 294.

48 North (1991) p. 97. 
innovation was an abandonment of economic equilibrium. Each change impels the relations in the market, making it impossible to reach the state of rest, which characterizes economic stability. This expression has had enormous success, but it does not capture the essence of the problem. Rather than destruction, one should speak of the retention and expansion of possibilities. The destruction would occur when a previously satisfied need could not be met with the new product. Creative innovation cannot be a reduction, but rather an enlargement of the satisfaction of needs and an enlargement in the possibilities of action. ${ }^{49}$ So, the new combinations create a new source of potential value. As Ghoshal, Bartlett and Moran (1999) say what we need is: «a new corporate philosophy that explicitly sees companies as value-creating institutions of society». .50

It is not strange that Ghoshal labels Chicago School model as "gloomy vision» with the following paragraph:

When Richard Possner claims that justice is important only because it leads to the avoidance of waste, he perpetrates absurdities in theory....When Gay Becker (1993) asserts that theft is harmful only because it diminishes productivity, he closes his eyes to all that proves incapable of quantification and falls victim of the «false consciousness» to which Isiah Berlin refers. ${ }^{51}$

In Becker's work, all reference to culture, like society, is reduced to arguments that appear within the variable social capital of the extended utility function.

\section{9) Structure of the model}

The theoretical conclusion can be explained in two points:

(1) Regarding Becker's work and neoclassical model, the hypothesis and the use of the as if Friedman (1953) clause states

\footnotetext{
49 Kirzner (2000) pp. 239-258.

50 Ghoshal, Bartlett and Moran (1999) p. 19.

51 Ghoshal (2005), p. 79.
} 
some properties of the economic agent which convert him into a mere caricature of human reality, converting his suppositions into mere ad hoc hypotheses:

- The definition of the economic agent continues to present grave deficiencies. His homo economicus is a passive optant when facing given alternatives.

- The means of the operations in which homo economicus carries out his activity is external to the model. The Beckerian economic agent does not have any active role in society and culture.

- The means-end relation is dislocated from its framework of reference. On eliminating all reference to the subjective aspect of the action, the alternatives that are presented to the agent economic are already given.

(2) Concerning the work of Mises: if really one wants to copy Physics, it is necessary to recognize that the role that is played in physics by the categories of space, time, substance, causality, action, and reaction, are converted into praxeological categories in the social sciences and not into a literal translation of these physical categories. Because in economics, we do not deal with bodies nor substances. We economists deal with meansends relations, which constitute the genuinely human world:

- The praxeological categories define the person as a creative and active optant of realities through the project.

- The socio-cultural framework, formed by the social and cultural institutions, constitutes the means of operations. The role of the person is active in the formation and maintenance of the institutions and in the transmission of the culture.

- The means-end relation is based on the historicity of the person. The project is the dynamic constitution of the structure of the ends and means. Economics becomes an objective science when focusing on the individual subject. 


\section{Methodological differences}

These two theoretical conceptions determine the two distinct methods of economic study:

TABLE 2

METHODOLOGICAL DIFFERENCES

\begin{tabular}{|c|c|c|}
\hline Point of comparison & $\begin{array}{c}\text { Ludwig von MISES } \\
\text { Austrian School }\end{array}$ & $\begin{array}{c}\text { G. BECKER } \\
\text { Neoclassical School }\end{array}$ \\
\hline 1. Type of reasoning. & $\begin{array}{l}\text { Deductive method: } \\
\text { individual action in the } \\
\text { social framework: } \\
\text { the interrelations } \\
\text { - appearance of indirect } \\
\text { exchange- market prices. }\end{array}$ & $\begin{array}{l}\text { Determination of the } \\
\text { extended utility function } \\
\text { and its restrictions. } \\
\text { Calculation of shadow } \\
\text { prices. }\end{array}$ \\
\hline $\begin{array}{l}\text { 2. Separation between } \\
\text { areas of study. }\end{array}$ & $\begin{array}{l}\text { Clear distinction between: } \\
\text { a) Non-monetizable social } \\
\text { interrelations. } \\
\text { b) Monetizable market } \\
\text { exchanges. }\end{array}$ & $\begin{array}{l}\text { There is no such } \\
\text { difference. All decisions } \\
\text { are expressed in money. }\end{array}$ \\
\hline 3. Formalism. & $\begin{array}{l}\text { Formal reasoning for } \\
\text { integrating human } \\
\text { creativity and historicity. }\end{array}$ & $\begin{array}{l}\text { Mathematical formulation } \\
\text { of the problem. }\end{array}$ \\
\hline
\end{tabular}

1) Type of reasoning

The Misesian method of reasoning is deductive; bearing in mind the radical difference that exists in Praxeology between the areas of study. It is always necessary to start from more general situations and then to introduce the elements necessary for the explanation of particular situations. Therefore, to arrive at the explanation of prices using the praxeological categories one must follow this process: (1) the explanation of the individual action. (2) Action in the social framework: the social interrelations. (3) From these interrelations, one must focus on the exchanges and within these on one group in particular: the commoditymoney-commodity: indirect exchanges. (4) The explanation of market prices starting from the valuations of the persons who intervene in the exchange. 
Becker's way of reasoning is totally distinct. In order to reduce all action to maximizing behavior, he defines a system of simultaneous equations that establish not only the variables that enter as arguments in the extended utility function, but also the relations that connect these variables together in order to formulate the restrictions.

\section{2) Separation between areas of study}

In Mises' work the difference between «Economics in the broad sense» and «Economics in the narrow sense»which correspond to the social interrelations in general, and to the market exchanges in particular, aim not to use market prices outside the context in which they are fully valid. Therefore, Mises' method is clear: in order to explain the social interrelations, they should not be reduced to monetary expressions, but rather one should use the praxeological categories. Unlike Mises, Becker's objective is precisely to reduce every human decision to monetary terms.

\section{3) Formalism}

The only way of integrating human historicity and creativity is to express them formally in words (verbal logic). It is not a question of trying to reject the use of mathematics on principle, but of recognizing that at the present time, the mathematical elements necessary for describing the richness of the person do not exist. Now we are suffering a very restrictive definition of scientific explanation which is reduced to mathematical models with testable propositions. But, what about the practical understanding of such complex phenomena as firms? As Ghoshal says:

Business could not be treated as a science, and we would have to fall back on the wisdom of common sense that combines information on «what is» with the imagination of «what ought to be» to develop both practical understanding of and some 
pragmatic prescriptions for "phenomena of organized complexity» that the issue of corporate governance represents. ${ }^{52}$

On the other hand, the reduced anthropological assumptions on which homo economicus is based generate very simple models that are suitable for use in calculating conditioned maximums and minimums. Once Becker has reduced all that is genuinely human to a useful value, it is easy to assign a mathematical variable to this human reality. All the reasoning in Becker's work is mathematical.

\section{IV}

\section{CONTRASTING BOTH APPROACHES}

1) With their growing interest in non-market phenomena, economists are often accused of «economic imperialism» for trying to include areas traditionally reserved for other social disciplines. This accusation can be understood in two ways: (1) it can refer to the enlargement of Economics. (2) It can refer to the definition of economic behavior.

If we are referring to the scope of Economics, the accusation of «economic imperialism» has no basis. The confirmation that the categories that we deal with in economics, the ends, the means, value, preference, choice are present in all human behavior, offers a reasonable argument to seek a common basis for all the sciences which study human behavior. On this point both Mises and Becker agree in pointing out the unchangeable reality of choice, which exists in all human behavior. But the enlargement of Economics raises the second and third questions. The two characterizations of economic behavior, which we have presented as possibilities of theoretical development are totally different. If we adopt Becker's characterization of economic behavior, then we may declare the reduction of all human behavior to maximizing utility behavior in a context

\footnotetext{
52 Ghoshal (2005) p. 81.
} 
of market equilibrium. In this case, the accusation of «economic imperialism» is totally appropriate. As regards that the theoretical mean for the enlargement of the scope of Economics is based on the application of the neo-classical paradigm, and all human aspects are reduced to prices. ${ }^{53}$

2) If we consider that the method gives us access to the reality of things, it is appropriate to ask ourselves: what real phenomena are susceptible to explanation using both methods of economic approach to human behavior? Taking into account that both authors and Schools defend the maximum area for the application of their method, the point that this paper is pointing out is this: the reduction of economization to simple decision making leaves no room for human reality. The movement from a situation of equilibrium to another mechanical and passive situation prevents us from recognizing the importance of man's activity as a source of the phenomena, which are the object of study. Becker's method, which attempts to explain all human behavior, constructs a fictitious world where the real man has no place. Münch takes the work of Becker as an example of this dislocation of the hypotheses with respect to the object of study ${ }^{54}$ and says about this: «for economic theory, these assumptions are ad hoc hypotheses outside their framework of reference». ${ }^{55}$ Becker starts from the decision that is already known, and constructs on his hypotheses a world that is supposedly theoretical that has nothing to do with reality. Münch defines the working method of this type of scientist in the following manner: "this method of introducing new objectives is frequently used to amour-plate economics against

${ }^{53}$ As Huerta de Soto points out: «ever the accusation of imperialism is not justified when it refers exclusively to the scope of the application of economic science, and not to the use of the neoclassical approach: from the Austrian point of view as well, since economics is considered a general theory of human behaviour, it is applicable to all the fields in which human beings act. Only when the conception based on the strictly rational homo economicus is applied is the accusation of imperialism clearly justified, not with regard to the scope of application of the economic point of view correctly understood but in respect of the neoclassical attempt to apply the strictly rationalist approach to all human fields», Huerta de Soto (1998) p. 103.

${ }^{54}$ Münch (1987) n. 13, p. 232.

55 Op. cit. p. 183. 
falsification. This means that the theoretician usually constructs the situation until it has "economic sense" again». ${ }^{56}$

The question to be asked is: what is the economic sense advocated by the neoclassical school? The Chicago School and M. Friedman are regarded as the champions of market economics and personal freedom. Thus Friedman says: «freedom as the ultimate goal and the individual as the ultimate entity in society». ${ }^{57}$ But with a neoclassical theory whose hypotheses are not realistic and with little predictive power, how can the liberalism of the neoclassical school be defended? There are no serious theoretical arguments. We may agree with Ghoshal and speak of liberalism as an ideology in its formulation by the Chicago School. As Ghoshal says: «If both common sense and empirical evidence suggest the contrary, why does the pessimistic model of people as purely self-interested beings still so dominate management-related theories? The answer lies not in evidence but in ideology». ${ }^{5}$

Though I see Ghoshal's analysis of the neoclassical model as correct, I cannot really agree with the theoretical alternatives that he proposes. Basically they are little more than a variant of the positivist method. Ghoshal considered a positive alternative to Friedman's negative ideological liberalism, centered on selfinterest, the conference on Economics, Values and Organization that took place at Yale University in April 1996. For Ghoshal, the positive side of those authors is based on the fact that they envisage: «the two two-way interactions between economic arrangements or institutions and preferences, including those regarding social status, the well-being of others and ethical principles». ${ }^{59} \mathrm{He}$ implies that there is an opposition between the individual and social norms, suggesting that any study centered on the individual excludes the principle of social norms. Thus he says: «First, in Friedman's words, "a major aim of the liberal

\footnotetext{
56 Op. cit. p. 179.

57 Friedman (2002) p. 6.

58 Ghoshal (2005) p. 83.

59 Op. cit., p. 86.
} 
is to leave the ethical problem for the individual to wrestle with". In other words, it can and indeed must be excluded from social theory. The way to do so is to base all theories on the assumption of homogenous human behavior based on self-interest». ${ }^{60}$ That is, for Ghoshal, the way to introduce ethics is to set society against the individual. But Ghoshal does not notice that this new approach uses the same neoclassical methodology. As the editors of the collected volume from that conference proclaim: «In this pathbreaking book, economists and scholars from diverse disciplines use standard economic tools to investigate the formation and evolution of normative preferences». ${ }^{61}$ That is, the new approach consists of going from the individual utility function to the social utility function. From the «negative» approach of liberal selfinterest we switch to the «positive» socialist approach of maximizing social utility. We stay exactly within the same neoclassical model and its aspiration of a rational construction of social reality. The core of my critique here is that the basis of rational choice is the individual maximization of any good or value, as is shown masterly by G. Becker and as we have shown here. Our critique centers on the hypotheses of the neoclassical model and its methodology and not on what goal is to be maximized by the consumer. So Ghoshal misses the point of the neoclassical model, if he considers that just by exchanging a negative approach based on self-interest - what he calls the «negative» individualism of the Chicago School, for a communitarianist "positive» approach of social utility (though both approaches are based on the same neoclassical methodology) the theoretical result will be different and its practical application successful.

As we have seen in section 3, within praxeology social institutions and culture are intrinsic to individual action. So in Mises praxeology we have the theoretical arguments to overcome the antagonism between individual liberty and social norm and culture that pervades the neoclassical model. Following the work of E. Husserl, as Mises did, we can consider that economic reality constitutes a part of what E. Husserl called Lebenswelt. He describes this network

60 Ghoshal (2005) p. 84.

61 Ben-Ner \& Putterman (1998). 
of relations and symbols that man lives socially, and which he transmits through generations. Let us say, therefore, that man is a with-being, implying that the essence of man is being-with. That is to say, to form himself as he is, other men and culture are essential. As Husserl points out: «to be human at all is essentially to be a human being in a socially and generatively united civilization». ${ }^{62}$ It is entirely appropriate, therefore, to define man as a with-being, denoting with this expression the essential opening of the person to his fellow men through society and culture. This definition of man clashes with dominant neoclassical economic view, in which man is reduced to a mere maximizer of utility. The aim of this article is to show the complexity of economic reality with all its social and cultural components. This is a reality, whose objective is the full development of the real possibilities of people. It is a development that cannot be reduced to mere monetary maximization, as is often done in the usual economic models.

\section{CONCLUDING REMARKS}

Hence my fear that the lack of recognition of the Austrian School, principally the work of Mises, its hypotheses based on a study of the individual and its theories and methodology, may have disastrous consequences. Firstly, the neoclassical model is unable to explain the failure of socialism; secondly, its inclination for a rational construction of society has taught and propagated the bad business practice from which we are now suffering. And thirdly, all these failings are causing a growing perception in society that the fault lies with the market economy itself and that the solution to the current social problems is to increase the role of the state. The view propounded is that we should switch to the new "positive» approach of maximizing social utility functions. That is, in theoretical terms we are returning to the situation of the 1920s,

\footnotetext{
62 Husserl (1954) p. 16.
} 
when the debate began on calculation in a socialist economy. Thus it will be understood that what I propose is to decidedly return to the theoretical path of Mises and Hayek.

To conclude I would like to recall the consequences of the neoclassical method - used in its «negative» individualist version from the Chicago School or in its "positive» communitarianist version - explained by Mises with great clarity:

\begin{abstract}
A new sophisticated version of the image of the perfect society has arisen lately out of a crass misinterpretation of the procedures of economics. In order to deal with the effects of changes in the market situation, the endeavors to adjust production to those changes, and the phenomena of profit and loss, the economist constructs the image of a hypothetical, although unattainable, state of affairs in which production is always fully adjusted to the realizable wishes of the consumers and no further changes whatever occur. In this imaginary world tomorrow does not differ from today, no maladjustments can arise, and no need for any entrepreneurial action emerges. The conduct of business does not require any initiative, it is a self-acting process unconsciously performed by automatons impelled by mysterious quasi-instincts. There is for the economists (and, for that matter, also for laymen discussing economic issues), no other way to conceive what is going on the real, continually changing world than to contrast it in this way with a fictitious world of stability and absence of change. ${ }^{63}$
\end{abstract}

\title{
BIBLIOGRAPHICAL REFERENCES
}

ARANZADI, J. (2006): Liberalism against Liberalism. Routledge, London. BAUER, P.T. (1987): «The disregard of reality», Cato Journal, Spring/ Summer, 7, 29-42.

BeCKer, G. (1976): The Economic Approach to Human Behaviour, The University of Chicago Press, Chicago.

${ }^{63}$ Mises (1966) p. 365. 
Becker, Gary S. and Murphy, Kevin M. (2000): Social Economics: Market Behavior in a Social Environment, Harvard University Press, Cambridge, MA.

Ben-Ner, A. and Putterman, L. (1988) eds.: Economics, Values, and Organization, Cambridge University Press, Cambridge, England.

COASE, R. (1988 [1937]): «The nature of the firm», The firm, the market and the law, University of Chicago Press, Chicago.

Friedman, M. (1953): Essays in Positive Economics, The Chicago University Press, Chicago.

- (2002): Capitalism and Freedom. (40 ${ }^{\text {th }}$ Anniversary Edition). The Chicago University Press, Chicago.

GHoshal, S. (2005): «Bad management theories are destroying good management practices», Academy of Management Learning \& Education, ,vol. 4, n.. 1 , 75-91.

Ghoshal, S., Bartlett, C., \& Moran, P. (1999): «A new manifesto for management», Sloan Management Review, (39): 9-20.

GHoshal , S. \& Moran, P. (1996): «Bad for practice: A critique of the transaction cost theory", Academy of Management Review, 1(1): 313-47.

Huerta De Soto, J. (1998): «The ongoing methodenstreit of the Austrian School», Journal des Économistes et des Études Humaines, 8(1): 75-113.

HuSSERL, E. (1954): Die Krisis der Europäischen Wissenschaften und die Transzendentale Phänomenologie, Martinus Nijhoff Publishers,La Haya.

KEYNES, J.M. (1953): The General Theory of Employment, Interest and money, Hartcourt Brace Jovanovich, New York.

KIRZNER, I.M. (1973): Competition and Entrepreneurship, The University of Chicago Press, Chicago.

- (1997): «Entrepreneurial discovery and the competitive market process. An Austrian approach», Journal of Economic Literature, 36: 60-85.

- (2000): The driving force of the market. Routledge, London.

Mirosky, P. (1989): More Heat than Light, Cambridge University Press, Cambridge, MA.

Mises, L. von (1966): Theory and History, $2^{\text {nd }}$ edition, Arlington House, New Rochelle, NY. 
- (1981): Epistemological Problems of Economics, New York University Press, New York.

- (1996): Human Action: A Treatise on Economics, B.B. Greaves (ed.), $4^{\text {th }}$ edition revised, Foundation for Economic Education, New York.

MüNCH, P. (1987): The theory of Action. Towards a New Synthesis Going beyond Parsons, Routledge and Kegan Paul, London.

NoRTH, D. (1991): «Institutions», Journal of Economic Perspectives, 5(3): 97-112.

Rosen, S. (1997): «Austrian and neoclassical economics: any gains for trade?» Journal of Economic Perspectives, Fall, 11, vol. 4, 139-152.

Rummel, R.P., SCHENDEL, D. \& TeECE, D.J. (1991): «Strategic management and economics», Strategic Management Journal, 2: 5-29.

SCHUMPETER, J.A. (1947): The theory of economic development. Harvard University Press, Cambridge.

Simon, H.R. (1985): «Human nature in politics: The dialogue of psychology with political science», American Political Science Review, 79: 293-304.

- (1991): "Organizations and markets», Journal of Economic Perspectives, 5, vol. 2: 25-44.

Stigler, G.J. and Becker, Gary S. (1977): «De gustibus non est disputandum», American Economic Review, 67: 76-90.

WiLLIAMSON, O.E. (1991): «Strategizing, economizing, and economic organization», Strategic Management Journal, 12: 75-94.

YEAGER, L.B. (1997): «Austrian economics, neoclassicism, and the market test», Journal of Economic Perspectives, Fall, 11, vol. 4, 153-165. 